\title{
Sustainable Development and Agriculture Sector A Case Study of Sindh
}

\author{
Muhammad Bachal Jamali \\ Associate Professor, Deptt: of Commerce \\ Shah Abdul Latif University Khairpur, Pakistan \\ Nanik Ram \\ Assistant Professor, Department of Economics \\ University of Sindh-Jamshoro, Pakistan \\ Ikhtiar Ali Ghumro \\ Assistant Professor, Deptt: of Commerce \\ Shah Abdul Latif University Khairpur, Pakistan
}

Faiz.M.Shaikh

Assistant Professor

Deptt: Agri: Economics

SZABAC-Dokri, Pakistan

E-mail: faizmuhammed_2000@yahoo.com

Received: September 20, $2010 \quad$ Accepted: October 9, 2010 doi:10.5539/jas.v3n2p178

\begin{abstract}
This research investigates the Sustainable Development and Agriculture Sector A Case Study of Sindh. Data were collected from 900 respondents from nine districts by using simple random technique, A Structural questionnaire was the basic tool for the measurement the sustainability in agriculture sector. It was revealed that diverting a sizeable area from the existing cropping sequence to other crops and enterprises to meet the ever-increasing demand for food, fibre, fodder, fuel while taking care of soil health and agro-ecosystem. The cost benefit analysis shows that they promise good returns to the farmers, though the returns on maize are not so promising. Natural conditions are particularly suitable to the districts of Nawabshah and Halla to the cultivation of maize. Similarly cotton may be a natural choice in Ghotki and Sukkur to reduce the cropped area under rice in the districts.
\end{abstract}

Keywords: Sustainable, Development, Agriculture

\section{Introduction}

Achieving self-sufficiency in food grains and food security for the people has underlined Pakistan's Agricultural development programs. The seed-fertilizer revolution that began in the late sixties, and supported by the appropriate agricultural policies, led to a cropping system that helped the country in attaining the said goal of self-sufficiency in food grain and food security. Inspite of structural shift towards industrialization, Agriculture is still the largest sector of Pakistan's Economy, with deep impact on Socio-economic setup. It is the source of livelihood of around 47.8 percent of the people employed in this sector and contributed 21.7 percent in the economy of Pakistan. However declining soil and land fertility, falling water table, growing dependence of chemical fertilizers and the excessive use of pesticides, all of which aggravate the problem of environmental degradation, have raised questions about the sustainability of the very technologies and the policies which from the basis of the present cropping system. 
Thus, there are emerges a growing dominance of the food crops over the non-food crops. Even with in the food crops, Rice and Wheat emerges the focal points of the cropping pattern. Different considerations, like meeting the food security, profit maximization and output maximization all found shelter under the rice-wheat cultivation. The increase in the area of Rice and Wheat reduced under the areas other crops like gram jowar, bajra, barley, maize, etc. trends in Kharif crops signify change in the area of various crops like rice, maize, bajra, jowar sugarcane and cotton. The rice and cotton shows an impressive increase in area while maize, jowar and bajra registers declines. Sugarcane too record a decline but the decline is not very significant. Likewise the trend in Rabi crops is in favour of wheat and oil seeds and is against the crops like barley and gram. On the whole, it is rice and cotton under Kharif crops and wheat and oil seeds under the Rabi crops, which have exhibited a raising trend. Two important factors, namely the government policies and modern technology in agriculture in the form of HYY of seeds, chemical fertilizers, pesticides, machinery and equipments, etc. contributed a lot to the emergence of the dominating wheat rice combination in the cropping pattern in Sindh. Profit/output maximization at the micro level, considerations for food security at the macro level and the subsequent technological development, all worked in tandom to produce the wheat-rice combination.

\section{Data Collection Methodology}

Data were collected from 900 respondents from nine districts by using simple random technique, A Structural questionnaire was the basic tool for the measurement the sustainability in agriculture sector

\section{Towards Sustainable Agriculture}

In the light of our discussion, at least, two types of measures related to sustainable agriculture may be suggested as damage control, exercise consists in incorporation certain short term measure within the existing cropping system so as to make it ecologically sustainable. The second exercise focuses on bringing about certain long-term changes in the present agricultural practices, including a shift from the chemical technology to a more eco-friendly biotechnology.

\subsection{Short Term Measure}

The emphasis, here, is to incorporate certain short term measures within the present cropping system so as to make it ecologically sustainable or at least to check the damages it is causing to the natural resources. The following measures can be suggested to induce sustainability in the state agriculture.

\subsubsection{Diversification of crops}

The existing cropping system has led to the marginalization of other crops and the main trend that appears from such practices is the crop specialization than to the crop diversification. The emphasis here is to restore the area earlier held by crops other than the rice and wheat. Crop diversification, thus means diverting a sizeable area from the existing cropping sequence to other crops and enterprises to meet the ever-increasing demand for food, fibre, fodder, fuel while taking care of soil health and agro-ecosystem

\subsubsection{Agro-forestry}

Trough agro-forestry, the mix of agricultural and forestry systems. We make use of number of trees and bush which enhance the nutrient values of cretin crops and plants. The bushes and trees with nitrogen fixing capacity have beneficial effects on plants growing with or after them. Trees also improve the microclimate by acting as wind-breaks by improving the water holding capacity of the soil, and by acting as shade trees for the livestock-so focusing the deposition of manure. Dlal (1999), while discussing the agricultural trends in Rural Sindh, has suggested new techniques for planting poplar tree to supplement the income for agriculture without adversely affecting the benefits form agricultural crops. The author has recommended and justified the cultivation of sugarcane also with the poplar plantation, which will contribute immensely in creating more income to the farmers and generating more employment and healthy environment for the society.

\section{Reeducation of Area under Wheat and Rice}

It has been suggested that at least 20 percent of the area presently under wheat and paddy need to be shifted to some other crops \{see e.g johl committee Report (1986) and Choudhry (1998). Of course, the alternative crops to wheat and rice must be less intensive in respect of the use of modern impact including water NAD at the same time be economically viable.

\subsection{Alternative Crops to Wheat}

The main complaint against wheat has been the tremendous expansion of area under its cultivation. The area under wheat, which was 31 percent in 1971-67 increased t o 41.8 percent in 2001-2. The main impact of the expansion in area under wheat has been on the cultivation of gram. Area under gram cultivation, which was 20 
percent in 2000-02 has been reduced to mere 9.96 percent in 2004. The ecological had been reduced to mere 10.96 percent in 2004. The ecological significance of gram cultivation follows from the fact that it increases the level of nitrogen in the soil, which is facing depletion due to wheat cultivation. So, gram may be suggested as an effective alternative to what both on economic and ecological grounds. Especially in districts of Jacobabad, Shikarpur, Sukkur, Ghotki and Khairpur where climate conditions are conductive to its growth. Similarly, cultivation of oilseeds in the districts of Thatta and Badin. may be suggested as the alternative to wheat cultivation on economic and ecological grounds

\subsection{Alternative crops to Rice}

The main complaint against the cultivation of rice that it has adversely affected the ground water table particularly in Zones I and II and parts of Zone III. Here tow crops, namely maize and jowar may be suggested as alternative to rice. Both these crops require comparatively suggested as alternative to rice. Both these crops require comparatively less water than rice. Moreover a cost benefit analysis shows that they promise good returns to the farmers, though the returns on maize are not so promising. Natural conditions are particularly suitable to the districts of Nawabshah and Halla to the cultivation of maize. Similarly cotton may be a natural choice in Ghotki and Sukkur to reduce the cropped area under rice in the districts.

\section{Damage Control Measures}

As has already been brought out, tow most serious ecological impacts of the present cropping system are its adverse impact on the ground water table and soil nutrition in the state, Accordingly we suggest below toe sets of measure one to deal with the adverse impact of the copping system on the ground water table and other for dealing of the cropping system on the ground weather table and other for dealing with its adverse impact of the natural healthy of soil in the Nausheroferoze, and Nawabshah districts.

a) Measure of Deal with the Groundwater problem.

\subsection{Make use of Rainwater}

It is suggested that Thar State should make use of rainwater, which at present is being allowed to go water via a network of drains. This can be down by setting up recharging station all along the length of drains where water can be round the clock in a full proof manner before injecitng it into the specially designed bore holes. It is also cautioned that if into the specially designed bore holes. It is also cautioned that if the present decline in the ground water is not arrested brackish water form adjoining areas can intrude into the set water zones. It may also be suggested that the bunds of paddy filed should be raised so as the store the maximums amount of rainfall to the extent the rainfall storage does not decrease the crop yield. It can further be argued that seepage though canal system can be effective source of water replenishment of retable reserves but this system should not be applied in areas which have poor quality ground water otherwise this seepage will be a net loss of water.

\subsection{Reeducation of Subsidies on Electricity and Installation of Pump sets}

There is a need of reviewing the policy on subsides specific relating to electricity and installation of the pump sets and tube wells has encouraged the farmers to over- irrigate their fields. A Punjab that the farmers on an average apply thirty-tow watering to paddy, well that the farmer on an average, apply thirty-two watering to paddy growing farmers have revealed above the recommended number of twenty-five watering. Second the flat tariff; irrespective of its pitch, induce the cultivation of heavily irrigation crops.

\subsection{Reduction in Ground Water Draft}

A reduction in ground water withdrawal will go a long way in checking the decline in water table in the Rural Sindh. A reduction in ground accomplished by making available to the farmers additional surface water for irrigation to substitute for ground water and its use for irrigation.

\subsection{Water Conservation}

Another option is to conserve or save water through adoption of more efficient irrigation management practices. This option assumes special significance in the cultivation of rice where farmers are known to use water to a level equivalent to the recommended one. There is an urgent need to educate farmers to improve their allocate efficiency in use of irrigation so as to promote more judicious and economic use of water especially in the cultivation of other crops option like sprinkler and drip irrigation need to be promoted.

b) Damage to soil health is mainly caused by the over use of chemical fertilizers. The supply of nutrients by chemical fertilizers is very much essential to achieve higher balance between different constituents (components) so as to promote their efficient use. Expert's guidance to farmer in the use of chemical fertilizers assumes significant roe here. 


\subsection{Livestock Measure and Composts}

These sources are often chapter, more efficient than inorganic compounds and focus on recycling of nutrients. Livestock manures form cattle, and chickens are important as they positively affect soil integrated farms have more earthworms than those under conventional management do. Composting is a technique of long standing that combines that use of animal manures green material and household.

\section{Conclusion}

We have considered two alternative cropping systems with an eye primarily on an ecological sustainable organization of agricultural practices in Rural Sindh. One short term cropping system which seeks modification within the existing cropping system and the other, a long term cropping systems which is aim at bringing about significant changes in the goals and method/techniques employed under the present cropping system. These two alternatives cropping systems may well look at as the two phases of a single integrated programs to be adopted in a step-wise/phased manner.

\section{References}

Bal Gulshan Singh. (1999). How to sustain Soil Health the Turbine Chandigarh April 10FAO (1989) Sustainable Agricultural Production: Implications for international agriculture Research Rome.

Baum II, C. L. (2002). A Dynamic Analysis of the Effect of Child Care Costs on the Work Decisions of Low-income Mothers with Infants. Demography, 39 (1), 139-64.

Berger, M.C. \& D.A. Black. (1991). Child Care Subsidies, Quality of Care, and the Labor Supply of Low Income, Single Mothers, The Review of Economics and Statistics, 70, 635-41.

Blau, D. \& P. Robins. (1988). Child-care Costs and Family Labor Supply. The Review of Economics and Statistics, 70 (3), 374-81.

Bormann, M.K, Quarm, D. \& Gideonse, S. (1984). Women in the workplace: Effects on families. Norwood, New Jersey: Ablex Publishing Corporation.

Connelly, R. (1992). The Effect of Child Care Costs on Married Women's Labor Force Participation. The Review of Economics and Statistics, 74(1), 83-90.

Doiron, D \& G. Kalb. (2005). Demands for Child Care and Household Labor Supply in Australia. The Economic Record, 81(254), 215-236.

Gips T. (1987). Breaking the pesticides Habit: Alternatives to Twelve Hazardous pesticides Minnesota: International services.

Singhal D.C. (2001). Environmental Impact of ground Water Development.

Table 1. Agriculture Growth Percent

\begin{tabular}{|l|l|l|l|}
\hline Year & Agriculture & Major Crops & Minor Crops \\
\hline $2002-03$ & 4.1 & 6.8 & 1.9 \\
\hline $2003-04$ & 2.4 & 1.7 & 3.9 \\
\hline $2004-05$ & 6.5 & 17.5 & 1.5 \\
\hline $2005-06$ & 6.3 & -3.9 & 0.4 \\
\hline $2006-07$ & 4.4 & 7.7 & -1.5 \\
\hline $2007-08$ & 1.1 & -6.4 & 10.9 \\
\hline $2008-09(\mathrm{P})$ & 4.7 & 7.7 & 3.6 \\
\hline
\end{tabular}

Source-Federal Bureau of Statistics-2009 
Table 2. Production of Major Crops (000 Tons)

\begin{tabular}{|l|l|l|l|l|l|l|}
\hline \multicolumn{1}{|r|}{ Year } & Cotton & Sugar cane & Rice & Maize & Wheat \\
\hline $2003-04$ & 10048 & 53419 & 4848 & 1897 & 19500 \\
& $(-1.6)$ & $(2.6)$ & $(8.3)$ & $(9.2)$ & $(1.6)$ \\
\hline $2004-05$ & 14265 & 47244 & 5025 & 2797 & 21612 \\
& $(42.0)$ & $(-11.6)$ & $(3.6)$ & $(47.4)$ & $(10.8)$ \\
\hline $2005-06$ & 13019 & 44666 & 5547 & 3110 & 21277 \\
& $(-8.7)$ & $(-5.5)$ & $(10.4)$ & $(11.2)$ & $(-1.6)$ \\
\hline $2006-07$ & 12856 & 54742 & 5438 & 3088 & 23295 \\
& $(-1.2)$ & $(22.6)$ & $(-2.0)$ & $(-0.7)$ & $(9.5)$ \\
\hline $2007-08$ & 11655 & 63920 & 5563 & 3605 & 20959 \\
& $(-9.3)$ & $(16.8)$ & $(2.3)$ & $(16.7)$ & $(-10.0)$ \\
\hline $2008-09(P)$ & 11819 & 50045 & 6952 & 4036 & 23421 \\
& $(1.4)$ & $(-21.7)$ & $(24.9)$ & $(11.9)$ & $(11.7)$ \\
\hline
\end{tabular}

Economic Survey of Pakistan-2009-10

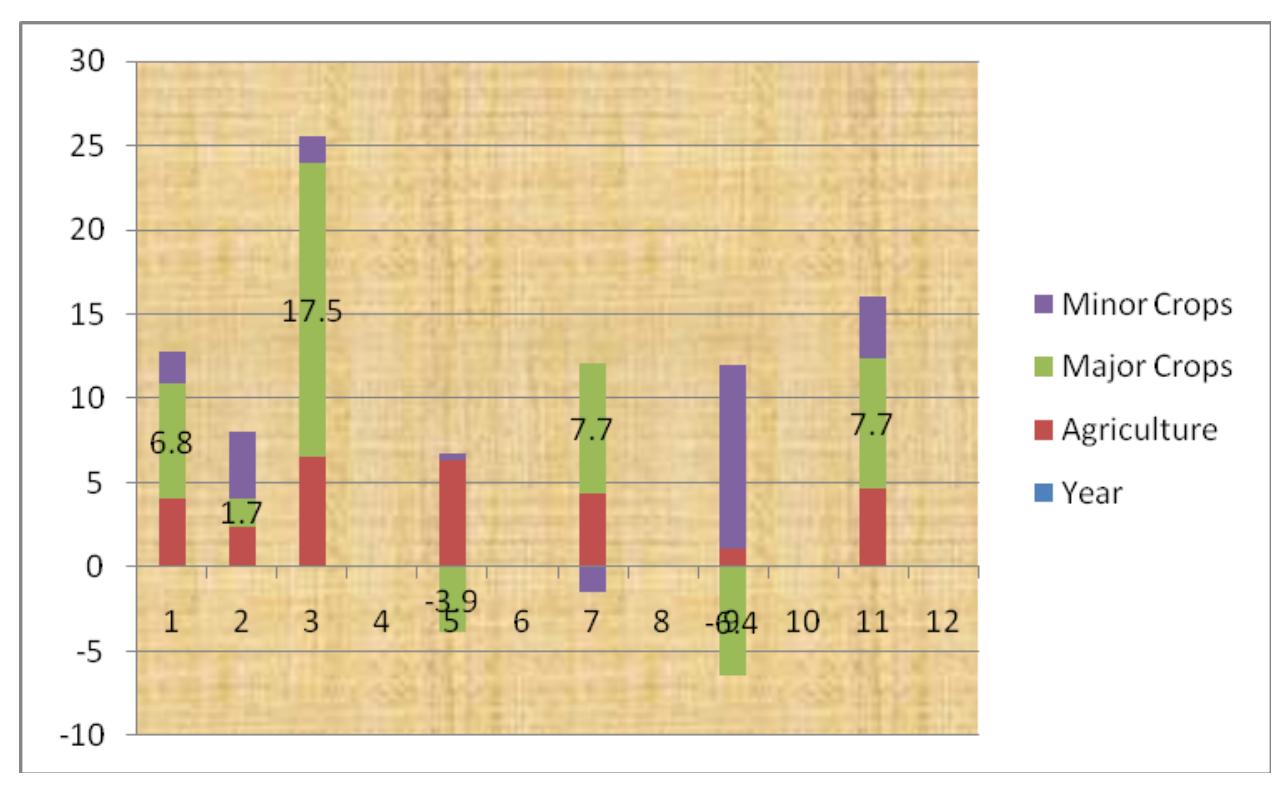

Resources Person Aid in Need, Col 1, No1.

Figure 1. 